\title{
Internalization of Falsafah "Peri Mestike Gayo" as an Effort To Developing Students' Characters Based on Local Authority In SMA 1 Takengon Aceh Central District
}

\author{
Indra', Al Rasyidin'2, Sukiman ${ }^{3}$ \\ ${ }^{1}$ Students of Postgraduate Program, UIN Sumatera Utara, Medan \\ 2Islamic Education Philosophy, UIN Sumatera Utara, Medan \\ ${ }^{3}$ Development Philosophy, UIN Sumatera Utara, Medan \\ indragayo1@gmail.com \\ ${ }^{*}$ Corresponding Author \\ Whatsapp number: [+62-85260465158]
}

How to Cite : Indra, I., Rasyidin, A., \& Sukiman, S. (2019). Internalization of Falsafah "Peri Mestike Gayo" as an Effort To Developing Students' Characters Based on Local Authority In SMA 1 Takengon Aceh Central District. International Journal for Educational and Vocational Studies, 1 (8), 817-822. DOI: https://doi.org/10.29103/ijevs.v1i8.2236

\section{ARTICLE HISTORY}

Received:7 October 2019

Revised: 25 October 2019

Accepted: 10 November 2019

\section{KEYWORDS}

Philosophy of Peri Mestike Gayo;

Fostering Character;

Local Wisdom;

\begin{abstract}
At present, there are two trending topic studies in the world of education that are hotly discussed, namely character education and local wisdom (indigenization). "Urang Gayo" is one of the ethnic groups in Indonesia that is rich in the noble values of Adat and its culture, until now they are still holding fast to defend it, because they believe that the customs and culture of Gayo can guide them in creating harmonization in the community, forming or fostering character, and does not conflict with the values of Islamic teachings. The internalization of Peri Mestike in education is part of efforts to foster character and as an effort to preserve the values of indigenous wisdom and culture of Gayo. The purpose of this study is to determine the importance of the internalization of the "Peri Mestike" (PM) Gayo philosophy in fostering the character of students, as well as the internalization process. The method used is a qualitative method with the ethnopedagogic approach, the data conclusions using the interview method with the strategy of "Swelling Gengku", (the method of imagery and class). This study shows that education must synergize with local wisdom in fostering the character of students because the culture is their identity. The results showed the importance of PM in internalizing and integrating with education as local wisdom and in schools, as for the process found first; through understanding PM by presenting qualified figures, second; with integration in learning material, third; through extracurricular activities, photos or posters that read PM sentences. Furthermore, the school through the principal's policy will continue to try to formulate with the teachers so that the PM can be a subject of local content.
\end{abstract}

This is an open access article under the CC-BY-SA license.

\section{INTRODUCTION}

Two themes have recently been often encouraged and become trending topics of study by observers and experts in Indonesian education, namely character education and local wisdom (indigenously). This can be seen from the number of research (studies or studies) carried out by the education community today, which is based on the many public scrutiny of local culture as a community philosophy that seems to be threatened with extinction because of the many foreign cultures that enter Indonesia making culture or values -the value of Indonesian people's lives has increasingly been abandoned, resulting in many peop- le losing their identity because of losing their culture. The development of national character should be not only the responsibility of the school but also the responsibility of the community and family together. The integration of these three elements (Tri-Center of Education) (Dewantara, 1962). becomes very important in advancing Indonesian education in preserving the values of local wisdom and building the character of Indonesian people.

Real educational institutions cannot be separated from cultural values, because students are born and developed in the cultural community of society, so as high as any knowledge that he can in the world of education, 
eventually they will return to people who hold to cultural norms. Therefore education must be based on culture so that when students return to society, the community does not feel alienated and alienated because the noble values of their culture are still attached to them and can socialize well as Ki Hajar Dewantara (1962) stated that education in the Republic of Indonesia must be based on the culture and society of the Indonesian people without covering themselves from the dynamics of global culture. The importance of culture as a foundation for education is because the culture is the identity of Indonesian people to distinguish it from other nations. Furthermore, Dewantara (1967) also emphasized that the emphasis on national culture was aimed so that the Indonesian nation would not dissolve and be swept away in the vortex of internationalization so that it would lose its identity as the people of a sovereign nation.

Gayo Is one of the ethnic groups in Indonesia whose geographical location is in the central region of Aceh Province. The Gayo Nation, or often called "Urang Gayo" which is rich in the noble values of Adat and their culture, up to now, they still hold fast to defend it. because they believe that the customs and culture of Gayo guide them to create humanization in the community, form characters, and do not conflict with the values of Islamic teachings, as contained in the Gayo philosophical expressions in the form of Peri Mestike "agama orum edet lagu zet orum sipet" meaning "religion and adat is an inseparable cohesiveness. 'This statement is reinforced by Pinan (1998), stating religion and adat as substances with character, as if they were inseparable. Adat is the fence of religion. Ibrahim (2013) also states that Islam and Gayo are like substances with properties; the two cannot be separated. He further explained that the implementation of Islamic teachings would be better and more effective if combined with the values and norms of the Gayo custom because the Gayo custom did not conflict with Islamic teachings and even supported the implementation of Islamic teachings.

Gayo philosophy is in the form of Peri Mestike, hereinafter referred to as PM. It is one of the inheritance of the ancestors of Gayo, who has become a custom and customs in the Gayo community as a guide for his life. As Joni (2016) explained that PM is a speech using the Gayo language, generally known by the Gayo community as Edet Basa (Indigenous Language) and functions as the philosophical life of the hereafter. And the PM is also believed to be able to form and foster the character uro Gayo towards better, especially in creating harmony in social life, because one of the functions of the PM for Gayo people is to foster and develop social relationships as well as guidelines between humans or groups (Joni, 2018).

In connection with the explanation above, the philosophy of Gayo in the form of PM needs to be recognized in education because education is a process that seeks to improve the quality of human beings in encouraging the development of Human Resources (HR), which can be a capital and tool for them to manage
Natural Resources (SDA) in their environment. In addition, education is also believed to be able to preserve the values of the indigenous community, so that their identity or identity is maintained at all times and able to adapt to modernity.

Internalization of the values of local wisdom through education is one of the efforts in realizing the character generation of the nation as Amin (2011) national character building has become an alternative in realizing the nation's generation who comprehends the nation's identity comprehensively. While Nindhika et al. (2018) also added that looking at it from an education point of view, character can be interpreted as a process of internalizing the main traits that characterize a society that is conveyed to students so that they can grow and develop into adult humans according to cultural values of the local community. It means that whatever knowledge they get from education and wherever they are, they still maintain their cultural values as their identity and identity as ethnic groups.

\section{METHODS}

This study belongs to the type of qualitative research conducted at SMA Negeri 1 Takengon, Central Aceh District. Qualitative research is a type of research that produces descriptive data that view research subjects holistically by setting researchers as instruments and conducting data analysis inductively (Moleong, 2012). Furthermore, Millan and Schummer (2001) say that qualitative research is an in-depth study that uses techniques dealing directly with people in their scientific settings in collecting data. In this case, the researcher found the dynamics of Indigenous and culture in the Gayo community about the Peri Mestike philosophy and its internalization process at the Takengon 1 High School as part of an effort to foster student character based on the values of local wisdom. The approach used in this research is the Ethno pedagogy approach, Bungin (2008) states that Ethno pedagogy is an approach to the practice of local wisdom-based education in various fields such as education, medicine, martial arts, environment, agriculture, economics, government, calendar system, and others.

Ethno pedagogy views local knowledge or wisdom as a source of innovation and skills that can be empowered for the welfare of society. Local wisdom is how knowledge is generated, stored, applied, managed, and passed on. This approach is used to identify social groups about the customs and culture of the Gayo people with a focus on understanding the cultural philosophy of Gayo in the form of Peri Mestike (PM), which is realized in their lives and their internalization in the world of education.

The data collected in this study uses an interactive interview method with informants, namely the principal, teachers, and traditional Gayo leaders who are considered to have the capacity related to this research, and the language used in the interview mostly uses the Gayo language. As confirmed by Spradley (2007) in ethnographic 
research studying the word of indigenous people occupies the highest priority. In this interview, the researcher also used a strategy "tengkah bengkuang gewat" (not directly asking the problem with the parable) and uses two techniques, namely; personal experience techniques (stories), and fishing techniques. This is done to get valid data because for parents or traditional leaders in Gayo who have high culture when asked directly, most of them do not provide valid information (actually). Besides that, the technique is done to avoid the nervousness or awkwardness of informants in answering questions from researchers. Furthermore, observation and documentation are also carried out to obtain other important data.

As a knife for analyzing data in this study, researchers used ethnographic research analysis that refers to Spredly, namely: domain analysis to determine the domains and symbols of PM, taxonomy to determine the classification of PM, component analysis to find components of the meaning of PM, and analysis theme, namely finding PM systematic on education.

\section{RESULTS AND DISCUSSION}

\section{Brief History of SMAN 1 Takengon (Senior High School)}

SMA Negeri 1 Takengon, Central Aceh Regency was established in 1957, occupying the location of the Tiong Hoa heritage building, located on an area of 3,048 square meters. At first there was only a main building with pillars in the Tiong Hoa style. At that time there were no high schools in Central Aceh District, so with the Central Aceh Regional Government's policy, a committee was formed to establish a high school.

While there is no school building, for 3 (three) years the SGB / SGA building has been used. After the decision, the high school was moved from the SGB / SGA building to the Tiong Hoa Experiment People's School, located on Hero Street. On October 5, 1959, this high school was to be public with SK Number: 72 / SK / 111/1959, hence the name of the school which from the name of the SMA Swatantera Laut Tawar became SMA Negeri ABC (ABC State High School).

a. In 1967, SMA Negeri ABC (ABC High School) became SMA Aceh Tengah (Aceh Tengah Senior High School)

b. In 1977 from SMA Aceh Tengah to SMA Negeri 1 Takengon

c. In 1997 from SMA Negeri 1 Takengon to SMA Negeri 1 Bebesen with SK Number 035/0/1997, dated March 7, 1997.

d. In 1992, the old building from Tiong Hoa was demolished, a new building that was built with 2 (two) floors with concrete / permanent construction.

e. As an upper secondary education institution, SMA Negeri 1 Takengon is the oldest and first public high school in Central Aceh District.

This school was born, grew and developed in the midst of a physical revolution to educate the nation's life. SMA
Negeri 1 Takengon has been led by 18 (seventeen) principals, including:

1. ABDULLAH ARMI ( Period 1957-1959)

2. M.AFFAN HASAN ( Period 1959-1960)

3. M. JOHAN ALAMSYAH (Period 1960-1970)

4. OESMAN MANAF (Period 1970-1978)

5. ISMAIL GENAP ( Period 1978-1983)

6. ABDULLAH HAKIM (Period 1983-1988)

7. Drs. M. AMIN TUJUH (Period 1988-1992)

8. Drs. ABDULlaH SULTAN (Period 1992-1996)

9. Drs. BERAMAD MUDEREJE ( Period 1996-2000)

10. Drs. JEMARIS ( Period 2000-2002)

11. Drs. BERAMAD MUDE REJE (Period 2002-2003)

12. MISBAHUDDIN, S.Pd., MM (Period 2003-2009)

13. SURYANI, S.Pd (Period 2009- 2010)

14. Drs.USWATUDDIN.M.AP (2010-2015)

15. SRIE HIDANAH (2015-2016)

16. PLT SUBHAN (2016-2018)

17. Drs. KHALIDIN,M.Pd (2018-2019)

18. PLT. SAHRUN,S.Pd. (2019 S/D until now).

(Souces: Data from Document of SMA Negeri 1 Takengon,2019).

In the age of 62 (sixty two) years of SMA Negeri 1 Takengon, many have given birth to the best sons and daughters of the region, who have been absorbed in various fields of life, there are those who serve in the region or outside the region, or abroad, both civil servants, self-employed and the military.

\section{Peri Mestike as an Effort to Foster Students' Character}

The PM who is known and understood by the Gayo people is a philosophy of life that governs governance, their behavior in life, Pinan (1998) refers to it as "Selpah Muruip Rum Mate" (view of life and death). One of the PM mentioned by Pinan in his book as "selpah murip rum mate is "Murip ikanung Edet, Mate ikanung Bumi, Murip Benar, Mate Suci" the literally meaning (Life is Adat, Death is in the Earth, Life must be True, Death must be Holy). From the explanation of the sentence, it can be understood that the Gayo people are very strong in holding their custom, which they make as a guideline or a way of life in creating harmony in society.

Why are Gayo's people strong in holding Adat and making it a way of life, because in Gayo's custom contains norms, rules and laws that guide them about the ways to behave in life. One of them is PM, which is the Gayo customary language which has power in their lives, as Joni (2018) said that the PM contained guidance on how to behave in living together. The PM is used by the Gayo community to convey messages, procedures, valuable advice, teachings or educate in conveying intentions, contents of hearts and minds and conveying information to the public. 
Next, based on the results of an interview with Joni/ Aman Rima ${ }^{1}$ (07 Mei 2019).

Meaning: This PM is a philosophical category, in the $P M$ there are symbols, sounds, and meanings that are human, so the laws and rules of life in interacting with the community are realized with the PM. And a PM can be in the form of a symbol, such as "Wei Senawat" (rattan cane), although he symbolizes an implicit message of ethics, the PM is more oriented to the formation of ethics. So if there is a Gayo person who is not ethical, it means that he does not understand the $P M$, so if the PM is internalized in education, we or the teacher used to be ethical, ie set an example.

There are several important things conveyed by Joni, namely first, PM is a philosophy, namely as a view or a way of life for Gayo urang in social interaction to create harmony in the family and community; secondly, this PM has the form of words as mentioned above and has a very deep meaning, there are also symbols and humane purchases that are required as rules and laws in their lives; third; PM is oriented towards ethics, which is to guide human behavior patterns for good ethics, or to guide people with good character; fourth, the PM has a great power and influence in their lives so that if there are people who are not ethically good they are said to have not understood the PM and have not made it a way of life, even if someone behaves badly, or is not polite and polite in speaking usually it is not gayo say 'oya jema gere muedet' (that's uncultured people).

Fifth, if this PM is internalized or taught to others, and is used to advise people, then those who teach or who give advice should use this PM, meaning that he must foresee it first and set an example for his community, if not, whatever what he advised would not be cared for and not carried out by his colleagues. A similar sentiment was also conveyed by ama Asfalah and ama M. Thaib $\mathrm{KB}^{2}$ in FGD (date: September 21, 2019).

"si munejera mulo mumetehie, (gurue mulo I pahaman kati baro nguk ijere ku kekanaka) iosah contoh oleh gurua"

That is how strong the Gayo people hold the custom because besides being a guideline in creating harmony in society, the PM and Gayo's Indigenous people provide guidance and care for maintaining a vertical relationship

1 Aman Rima, is a famous call among the gayo community, because in gayo for those who are married and have children, the name is personally recognized as "tabu atau tidak elok" to be called, then Aman Rima (Rima's father) is a title that can be called as attributed to her first child named Rima. See also in Mahmud Ibrahim, (2013: 93).

Ama Asfalah and Ama M Thaib KB are community leaders and members of the Majelis Adat Gayo (MAG) who provided much input and direction during the Focus Group Discussion held at the MAG Hall on Saturday September 21, 2019. with the Creator, and Horizontal with humans and the universe. This means that the Gayo tradition is in line with Islamic teachings. As mentioned above, they believe that Indigenous Gayo is not contrary to Islamic teachings and is human in nature. How do they maintain relations with Allah (God) (Hablum Minallah), Relationships among humans (Hablum Minannas), and human relations with nature (Hablum Minal 'Nature).

This PM is very important to be included in education, because in addition to preserving the Gayo philosophy and customs inherited from the ancestors, the PM can also foster the character of the students towards a better direction. Maya Agusyani / Inen Uti as a teacher of the SMAN 1 Takengon stated, It turns out that PM and Gayo songs or syaer and all that is in our customs and Gayo culture are all conveyed to nature and related to human character. One of them when dissecting the philosophical meaning contained in the song "Merbuk" even though the song contains the characteristics of birds, namely "Merbuk, Cincim Pala, Birah Mata, and Kalang Geguk" turned out to be Siopatni ara Jema, (apparently the four bird traits this exists in humans) and is related to human character today. This means it turns out that the song is not just describing the story of a bird, but its meaning explains about typical humans. (interview on September 19, 2019).

Based on the results of the interview it can be concluded that PM also exists in the form of songs or poems (poetry) Gayo that can shape and foster students' character. Furthermore, Mr. Dirwan/Aman Nazli explained that the philosophy of PM Urang Gayo is very important iayon (internalized) in education, because usually parents first teach their children with philosophical words / PM "wien ike remalan I arap ni jema gelah jeroh "remalan bertungket, peri berabun" "remalan enti begerdak, becerak enti segak" it means that it leads their children to behave politely and politely in speaking, if it is associated with education it means advice for noble character, if now with the new language called character. (interview on September 18, 2019).

Based on the above explanation this PM contains good values, for Gayo people, this PM is used as a way of life and can be used to educate their children both at home and at school.

\section{The Process of Internalizing the Peri Mestike in Schools}

The internalization of the Gayo philosophy in the form of PM into educational institutions is part of the effort to prepare and form a generation of characters who behave in accordance with customary and cultural norms that apply locally and nationally so as to create a harmonious order of life, besides that PM internalization also aims to prepare generations which will preserve the noble values of local and national culture. Tilaar (2012) states, educational institutions carry out the mandate to prepare students to be able to survive and form characters in accordance with the values that apply locally, nationally, 
and globally or humanization. Furthermore, Musanna (2017) states that Education is an inseparable part of the culture. Education must be based on a dynamic culture and experience continuous adaptation.

The inheritance of the Gayo philosophy or PM in schools is part of the effort to preserve customary norms that have noble values (internalization of local wisdom or indigenousity) contained in the Gayo community is a concept that seeks to foster the character of the younger generation (students), namely the character of regionalism, warm and religious. As stated by Bentara Linge in his book Uswatuddin and Joni (2018) said that in addition to building regional and religious character, the application of these customary norms to education (internalization of indigenousity) is also an effort to improve and develop the morality of Karimah and noble character towards others, nature and build good relations with 'god' as well as the main objectives of the program "Serahen Anak Ku Tengku Guru, Tingok Sino, Serahen Ulak Ku Urang Tue," is mainly to revive customary norms and Gayo Cultural values, then as an effort to prevent moral and moral degradation that is currently happening, both at the student level and the community in general.

"Serahen Anak Ku Tengku Guru, Tingok Sino Serahen Ulak Ku Urang Tue," the expression of Gayo language if transcribed to Indonesian means' Submitting children or students to teachers with Gayo traditional ceremonies, parents visiting schools to see the development of their children and know the obstacles and obstacles experienced by their children in learning, and the surrender of the child or student returns from school to parents after they finish, graduate, or graduate from school '. This is part of an effort to synergize the role of the tri education center in developing education, and shape the character of students.

Dewantara states that education is an effort to promote the growth of character (mental strength, character), mind (intellect) and the child's body (Dewantara, 1977). The process of internalization of Peri Mestike in schools as an effort to shape and foster student character can be done in various ways, including by integrating with subjects, meaning that this PM can integrate with other subjects, namely when explaining the material especially in moral subjects, moral education and so forth. Pak Dirwan, said that in the Takengon 1 High School, the PM internalization process was carried out by tucking in (explaining) when explaining the material, like I taught PPKN when the material on morals was related to the philosophy of Gayo (PM) like "remalan bertungket peri berabun".. The same thing was also said by Nurmawati / Inen Epi, she said I as a religious teacher when explaining the material to include PMs such as "mujurah enti munulak, mujangko enti munyintak" in charity material. (interview on September 19, 2019)

From this explanation it is illustrated that this PM provides guidance to each individual to behave well in accordance with human nature. The meaning of human nature is a tendency towards goodness and truth, we all understand that humans really like good things because it is a nature given by Allah (god) that is instilled into each individual human.

Furthermore, Mrs. Vera Hastuti / inen Aufa, said that the process of internalizing PM in this school is currently still on the creativity of teachers in integrating in subjects, and occasionally the school invites experts or traditional leaders to discuss themes about the philosophy of Gayo, because students also often appear in the regional arts and culture creativity contest. So to teach children, we invite people who are qualified in that field. (interview on September 20, 2019).

In this case the PM internalization process at SMA Negeri 1 Takengon meanwhile is still centered on the teacher's creativity and has not been used as a subject for local content. Pak Sahrun as the school principal also stated that we (in this school) have not yet been formulated in a special subject on Gayo custom or local wisdom, but in the future we are trying to formulate it, and to make some kind of posters, pictures or photographs to be placed in walls, parks and rooms written in PM. So that teachers and students can understand and easily process the internalization in learning. (interview, 18 September 2019).

From the foregoing, principals and teachers are very enthusiastic about PM internalization at Takengon High School 1, and the school will continue to make maximum efforts in formulating and applying it. Because they also believe that the PM contains educational values that boils down to or oriented to character building.

Based on the findings of the above research, the PM needs to be internalized in education as an effort to shape the character of students who have the power of reason, religious, and good personality, because PM is a form of advice that is metaphorical and euphemistic (Joni, 2018) that can maintain the maruah speakers and speech partners. Besides that, the community believes that education is able to preserve the values of local wisdom in developing the potential of students.

\section{CONCLUSION}

Based on the results of research on the internalization of the Gayo Peri Mestike philosophy in fostering the character of students at SMAN 1 Takengon, it shows that the Gayo PM philosophy is important for internalization in education, because PM is very helpful for teachers in fostering student character with local wisdom values. In general, this PM is used by the Gayo family and community to form and foster the character of their children at home and cross the community, so it would be nice for the PM to also be used by schools in fostering the character of their students.

The PM internalization process at Takengon 1 Public High School was carried out in various ways, including; The teacher first tries to understand the PM, integrates it in the subject, especially when explaining the material, the school invites traditional leaders and reviewers to provide 
understanding to teachers and students related to edet's Gayo and understands the meaning of the PM, the principal and the teacher try to formulate the concept of wisdom education local so that this PM becomes one of the materials in local content, and strives to make posters, photos and writing on walls and parks with PM sentences which is one way to include them in education.

\section{REFERENCES}

Ama Asfalah dan Ama M Thaib KB.; merupakan tokoh masayarakat dan anggota Majelis Adat Gayo (MAG) yang banyak memberikan masukan dan arahan pada saat Focus Group Discussion (FGD) yang digelar di Aula MAG hari Sabtu 21 September 2019.

Amin, S. (2011). Pewarisan Nilai Sejarah Lokal Melalui Pembelajaran Sejarah Jalur Formal dan Informan Pada Siswa di SMA Kudus Kulon. Jurnal Paramita: Historical Studies, 21 (1).

Bungin, B. (2008). Penetlitian Kualitatif, Jakarta: Kencana.

Dewantara, K., H. (1962). Karya Ki Hajar Dewantara: Bagian Pertama. Yogyakarat: Pertjetakan Taman Siswa.

Dewantara, K., H. (1977). Karya Ki Hajar Dewantara: Bagian Pertama. Yogyakarat: Majelis Luhur Taman Siswa

Ibrahim, M. (2013). Nilai-Nilai Pendidikan Islam Dalam Adat Gayo. Banda Aceh: Al-Mumtaz Institut.

James P. Spradley, (2007). Metode Etnografi, Yogyakarta: Tiara Wacana.

Joni MN., (2016). Filsafat Daya Bahasa dan Adat Gayo. Takengon: Yayasan Pendidikan Prima.

Joni, (2018). Kajian Pragmatik Tuturan Bijak Peri Mestika Dalam Budaya Gayo, (Banda Aceh: Balai Pelestarian Nilai Budaya Aceh, Jurnal SUWA: Jurnal Sejarah dan Nilai Budaya, 32(1) Tahun, 2018), h. 20-34.

Moleong, L., J., (2012). Metode Penelitian Kualitatif. Bandung, Remaja Rosdakarya

Millan, J., H., M \& Schummer, S., (2001). Research in Education; A. Conceptual Intuduction, New York: Longman.

Musanna, A (2017). Indigenisasi Pendidikan: Rasionalitas Revitalisasi Praksis Pendidikan Ki Hadjar Dewanta, Jurnal Pendidikan dan Kebudayaan, 2 (1) Juni 2017. h. 122-130.

Nindhika, et al (2018). Internalisasi Nilai-Nilai Sosial Budaya Melalui Pembelajaran Sejarah Pada Kelas X SMA Semesta Semarang Tahun Ajaran 2017/2018. Jurnal: Indonesian Journal of History Education, 6(1). 2018),15-32.

Pinan, A., R., H., A. (1998). Hakikat Nilai-Nilai Budya Gayo Aceh Tengah. Banda Aceh, CV. Rina Utama.
Sumber Data dari Dokumetasi Tata Usaha SMA Negeri 1 Takengon, 2019.

Tilaar, H., A., R., (2012). Kaleidoskop Pendidikan Nasional. Jakarta: Gramedia.

Uswatuddin \& Joni. (2019). Serahen Anak Ku Tengku Guru, Tingok Sino Serahen Ulak Ku Urang Tue. Takengon: Dinas Pendidikan Kabupaten Aceh Tengah. 